\title{
Ultra-wideband bandpass filter with notch band based on quadratic Koch Island structure
}

\author{
Manju Bhaskar', Thomaskutty Mathew ${ }^{2}$ \\ ${ }^{1,}$ Department of Electronics, School of Technology and Applied Sciences \\ Edappally, Kochi, India \\ 2, Department of Physics, GITAM School of Science \\ Bengaluru Rural, Karnataka, India
}

\section{Article Info}

Article history:

Received Jun 13, 2020

Revised Aug 23, 2021

Accepted Sep 17, 2021

\section{Keywords:}

Ultra-Wideband

Notch

Quadratic Koch Island

Bandpass Filter

Microstrip

\section{Corresponding Author:}

Dr. Thomaskutty Mathew

Department of Physics

GITAM School of Science

Bengaluru Rural, Karnataka, India

Email: tmathew@gitam.edu

\begin{abstract}
An ultra-wideband bandpass filter with a notch band centered at $7.2 \mathrm{GHz}$ is proposed to remove the interference caused by satellite communication signal coexciting within the ultra wide band. The filter comprises of two seperated quadratic koch island structures connected to the main transmission line to generate the notch band at the desired frequency. The designed ultra wide bandpass filter passes frequencies from $3.09 \mathrm{GHz}$ to $10.61 \mathrm{GHz}$ with a notch band from 7.12 to $7.46 \mathrm{GHz}$ centered at $7.2 \mathrm{GHz}$ and with a rejection level of $21.3 \mathrm{~dB}$. The resonant frequency and bandwidth of the notch can be varied by the variation in the physical parameter of the filter. The proposed filter is fabricated, tested and compared with simulated results.
\end{abstract}

Copyright (c) 2021 Institute of Advanced Engineering and Science. All rights reserved.

\section{INTRODUCTION}

Ultra-wideband (UWB) is a very attractive wireless transmission technology due to its advantages of being short-range, low power, having high data rate and short broadcast time using $3.1-10.6 \mathrm{GHz}$ unlicensed frequency spectrum. The disadvantage of UWB technology is the existence and interference caused by other radio based technologies like Wi-Fi, Wimax, Bluetooth, Zigbee, satellite communication etc which lies within the same frequency spectrum of UWB. Bandpass filters passing the UWB frequency band and rejecting the bands alloted for other technology which cohabit within the UWB sprectrum, finds much interest in moderm wireless communication systems. The conventional methods for achieving this consists of bandpass filter design incorporating a high pass and a low pass filter together in a single structure [1, 2]. It is difficult to achive compactness for such designs and also impedance matching networks are needed at the output and input stages. Other UWB bandpass filter designs include the incorporation of stepped-impedance resonators [3-6], defected microstrip structures [7], stub loaded resonators [8-11], defected ground stuctures [12], CRLH Cell [13, 14], multi mode resonators [15-18].A resonator combining interdigital structure and defected ground structure is used for designing UWB filter with a notch in [19].The coupled sections which are tightly aligned needs high accuracy in manufacturing in stepped impedence resonators and multi mode resonators and size of these filters are also not compact. Also tuning of transmission zero is not so easy in all designs. In stepped impedance resonators, the control of resonant frequencies is difficult to attain and are rarely reported. Defect ground structure can effectively reduce the size of the filter, but these structures face leakage of the floor and also attaining broadband characterisicsis difficult. The microstrip filter based on defected microstrip structure can solve the floor leakage problem and UWB filters incorporated with CRLH Cell can reduce the size of the filters. 
This paper presents the design and development of microstrip UWB notch filter based on quadratic Koch island structure to remove the interference of satellite signal coexcisting in the UWB band.The proposed design enables the tuning of the resonant frequency of the notch by varying the size of the notch depth of the quadratic Koch Island loaded to the transmission line.

\section{METHODOLOGY}

\subsection{Quadratic Koch Island Generation}

The design of the filter is based on quadratic Koch Island fractal. The initiator of this fractal structure is a square shown in figure 1(b) and generator given in Figure 1(c) is applied to each side of the square. Performing the first iteration we get the Koch Island structure with the same area of the initial square but the circumference seen increased as given in Figure 1(a).With application of each iteration on the fractal, the fractal section length 1 (n) decreases as given in the equation (1) and the circumference $\mathrm{C}$ increases for each iteration and as given in the equation (2) where $x 0$ is the side length of the square and $\mathrm{n}$ is the number of times the fractal iteration is carried out.As the iterations tends to infinity the over all length terminates at a constant value and $\mathrm{C}$ tends to infinity keeping the area constant[20].

$$
\begin{gathered}
l(n)=\left(\frac{1}{4}\right)^{n} x 0 \\
C=4\left(2^{n} \times 0\right)
\end{gathered}
$$

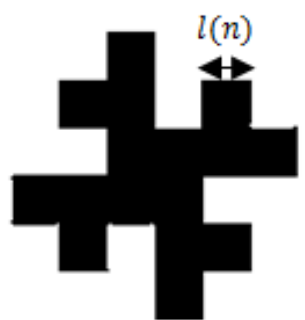

(a)

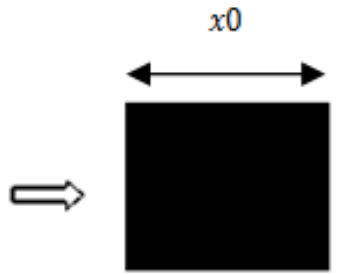

(b)

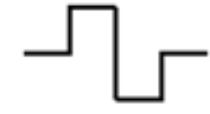

(c)

Figure 1. (a) Quadratic Koch Island after first iteration (b) Square Initiator (c) Generator

\subsection{Filter Structure}

The proposed filter structure has a feeding microstrip transmission line with width $\mathrm{W}$ and height $\mathrm{h}$. For $\mathrm{w} / \mathrm{h} \geq 2$ and characteristics impedance $\mathrm{Z}_{\text {line }}=50 \Omega$ for the matching conditions on input and output ports, the expression for $\mathrm{w}$ of the feeding microstrip line is given by equation (3) where $\varepsilon_{\mathrm{r}}$ is the relative dielectric constant of the substrate [21].

$$
w=\frac{2 h}{\pi}\left\{\left(\frac{60 \pi^{2}}{Z_{\text {line }} \sqrt{\varepsilon_{r}}}-1\right)-\ln \left(2 \frac{60 \pi^{2}}{Z_{\text {line }} \sqrt{\varepsilon_{r}}}-1\right)+\frac{\varepsilon_{r}-1}{2 \varepsilon_{r}}\left[\ln \left(\frac{60 \pi^{2}}{Z_{\text {line }} \sqrt{\varepsilon_{r}}}-1\right)+0.39-\frac{0.61}{\varepsilon_{r}}\right]\right\}
$$

Two symmetric and offset quadratic Koch island structure with equal side lengths $\mathrm{W}_{\mathrm{a}}$ and $\mathrm{W}_{\mathrm{b}}$ are loaded to the transmission line with a distance $\mathrm{W}_{\mathrm{c}}$ apart to get an ultra wideband with notch characteristics. The desired passband is attained by dual stub matching technique used for filter designs [22]. The first iterated quadratic Koch fractal structure has an optimized side length of $15 \mathrm{~mm}$ positioned $17.59 \mathrm{~mm}$ length apart in the filter structure as shown in the Figure 2.The design and simulations are performed in CST Microwave Studio to get optimized parameters. The prototype of the filter is fabricated using RT Duroid 5880 substrate with $\epsilon_{\mathrm{r}}=2.2$ and height $\mathrm{h}=0.787 \mathrm{~mm}$. The measurements are taken using vector network analyzers. The simulated and measured results are in good agreement with each other. The optimized design parameters in $\mathrm{mm}$ for the realized filter are given in Table 1.

Table 1. Optimized design parameters (dimensions in $\mathrm{mm}$ ) of the filter.

\begin{tabular}{cccccc}
\hline $\mathrm{W}_{\mathrm{a}}$ & $\mathrm{W}_{\mathrm{b}}$ & $\mathrm{W}_{\mathrm{c}}$ & $\mathrm{W}$ & $l(n)$ & $x 0$ \\
\hline 15 & 15 & 17.59 & 2.91 & 2.5 & 10 \\
\hline
\end{tabular}






Figure 2. Layout of the proposed UWB notch filter.

\section{RESULTS AND DISCUSSION}

The simulated and measured S parameter characteristics of the Ultra Wide Band notch filter based on Koch fractal is shown in Figure 3. The filter characteristics is having a notch band from $7.12 \mathrm{GHz}$ to 7.22 $\mathrm{GHz}$ separating two wide pass bands from 3.38 to $7.11 \mathrm{GHz}$ and $7.23 \mathrm{GHz}$ to $9.66 \mathrm{GHz}$. The pass band of the filter is from $3.38 \mathrm{GHz}$ to $9.7 \mathrm{GHz}$ with the notch central frequency at $7.2 \mathrm{GHz}$. The notch rejection level is at $21.2 \mathrm{~dB}$. The pass band insertion loss for the filter is $0.39 \mathrm{~dB}$. The slight variation in the measured and simulated plots is due to the impedence mismatch between the connectors of the cable to the device or the substrate loss.

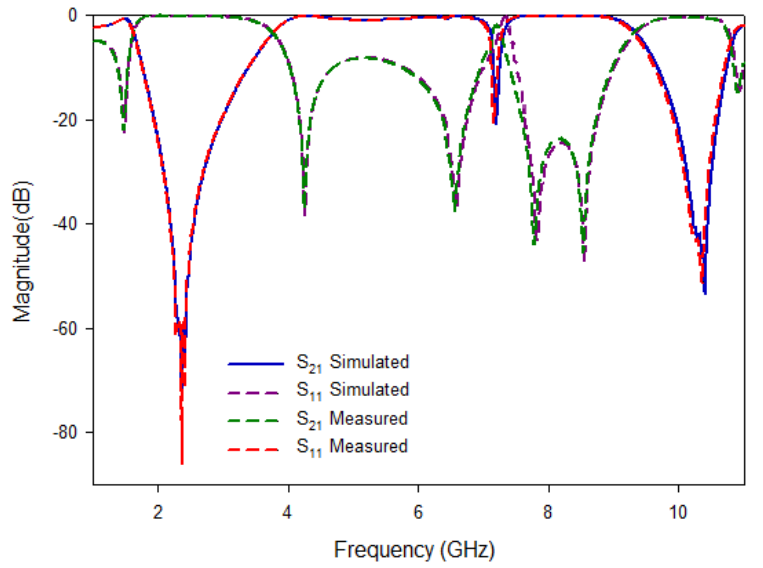

Figure 3. S Parameter Characteristics of the Ultra Wide Bandpass filter with Notch Band

\subsection{Tuning of the Notch Band Frequency and Notch Bandwidth}

Figure 4 (a) and (b) depicts the layout of the filter with notch depth $\mathrm{t}=0.5 \mathrm{~mm}, 1.0 \mathrm{~mm}$ respectively from the notch margin of the standard Koch Island filter shown in Figure 2. The simulated $S_{21}$ and $S_{11}$ characteristics of the UWB Koch island filter with varying values of notch depth trom the notch margin of the standard Koch Island filter is shown in Figure 5(a) and (b). The frequency of the notch band, bandwidth of the notch and the upper frequency skirt varies as the $t$ value varies.As the value of $t$ increases towards the inner part of the Koch Island from the margin the center notch frequency shifts towards the lower frequency side.The bandwidth of the notch decreases and the upper frequency limit of the UWB frequency liitdeceases. The lower frequency limit is have no significant change. The various performance characteristics of the filters shown in figure 4 are tabulated in the Table 2.

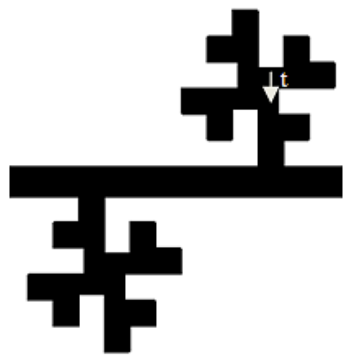

(a)

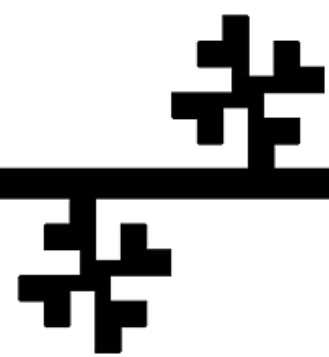

(b)

Figure 4. Layout of the Koch Island UWB Filters with varying t values at(a) $.5 \mathrm{~mm}$ (b) $1.0 \mathrm{~mm}$ 




(a)

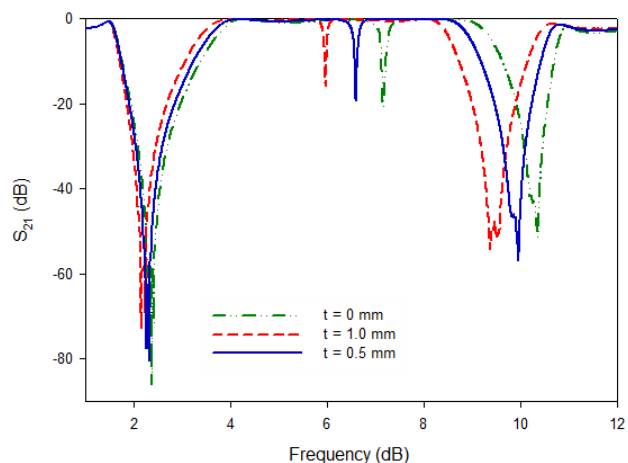

(b)

Figure 5. S Parameter Characteristics of the UWB Koch Island filter for varying t values (a) $S_{11}$ Plot (b) $S_{21}$ Plot

Table 2. Performance Characteristics of the UWB Koch Island Filters

\begin{tabular}{|c|c|c|c|c|c|}
\hline $\begin{array}{c}\text { Performance } \\
\text { Parameter }\end{array}$ & $\begin{array}{c}\text { Notch } \\
\text { Central } \\
\text { Frequency } \\
(\mathrm{GHz})\end{array}$ & $\begin{array}{c}\text { Notch } \\
\text { Bandwidth } \\
(\mathrm{MHz})\end{array}$ & $\begin{array}{c}\text { Lower } \\
\text { Frequency } \\
\text { Limit } \\
(\mathrm{GHz})\end{array}$ & $\begin{array}{c}\text { Pass band } \\
\text { Insertion loss } \\
\text { and Notch } \\
\text { Signal } \\
\text { Rejection } \\
(\mathrm{dB})\end{array}$ & $\begin{array}{c}\text { Upper } \\
\text { Frequency } \\
\text { Limit (dB) }\end{array}$ \\
\hline $\begin{array}{c}\mathrm{t}=0.0 \mathrm{~mm} \\
\text { (Fig 2) }\end{array}$ & 7.20 & 145 & 2.41 & $0.49,20.5$ & 10.31 \\
\hline $\begin{array}{c}\mathrm{t}=0.5 \mathrm{~mm} \\
(\text { Fig } 4 \mathrm{a})\end{array}$ & 6.59 & 132 & 2.31 & $0.23,19.24$ & 9.98 \\
\hline $\begin{array}{c}\mathrm{t}=1.0 \mathrm{~mm} \\
\text { (Fig 4 b) }\end{array}$ & 5.97 & 108 & 2.29 & $0.21,15.84$ & 9.59 \\
\hline
\end{tabular}

The current distribution on the surface of the filter at pass band frequency $5.5 \mathrm{GHz}$ and at the notch band $7.20 \mathrm{GHz}$ is shown in figures 6 (a) and (b) respectively. The current density inside the quadratic Koch Island structure increased at the notch band prohibiting $7.2 \mathrm{GHz}$ center resonant frequency.Figure 7 shows the photograph of the quadratic Koch Island UWB filter.The comparison of the proposed work with some of the reported UWB filters with notch band is shown in Table 2. Compared to the filters mentioned, the proposed work is not having any coupled structures or gaps between the transmission lines. This helps to reduce the losses caused and also makethe filter, simple in structure. The tuning of notch band central frequency and bandwidth of the notch band can be simultaneously done by controlling a single parameter $t$, the notch depth.In the reported papers given in Table 3, various performance characteristics are controlled by varying more than one physical dinemsions. The insertion loss is very low as $0.39 \mathrm{~dB}$.

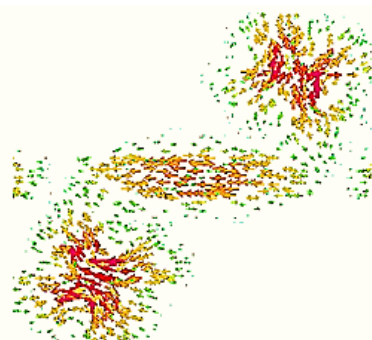

(a)

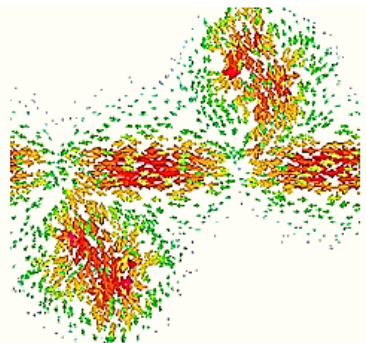

(b)

Figure 6. Surface Current Distribution at (a) $5.5 \mathrm{GHz}$ (b) $7.20 \mathrm{GHz}$

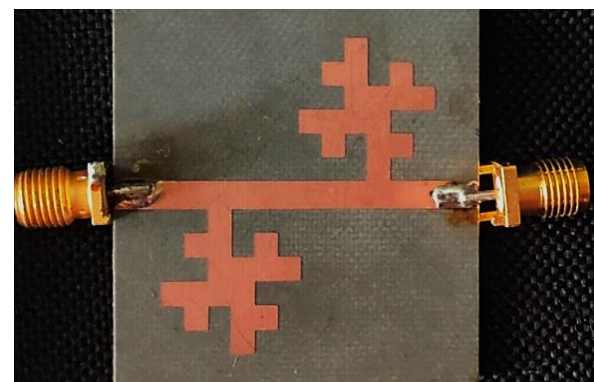

Figure 7. Prototype of the UWB Quadratic Koch Island Filter. 
Table 3. Comparison with some reported UWB filters with notch band

\begin{tabular}{|c|c|c|c|c|c|}
\hline Ref & $\begin{array}{c}\text { UWB } \\
\text { Pass } \\
\text { Band } \\
(\mathrm{GHz})\end{array}$ & $\begin{array}{c}\text { Center } \\
\text { Notch } \\
\text { Frequency } \\
(\mathrm{GHz})\end{array}$ & $\begin{array}{c}\text { Overall } \\
\text { Size } \\
\text { (mm } \times \mathrm{mm})\end{array}$ & $\begin{array}{c}\text { Notch } \\
\text { Band } \\
\text { Rejecion } \\
(\mathrm{dB})\end{array}$ & $\begin{array}{c}\text { No: } \\
\text { of } \\
\text { Notches }\end{array}$ \\
\hline$[9]$ & $2.8-11.8$ & $3.6 / 5.9 / 8.0$ & $31 \times 20$ & $>10$ & Three \\
\hline$[11]$ & $3.6-10.1$ & 6.0 & $20 \times 15$ & $>20$ & Single \\
\hline$[13]$ & $3.1-10.6$ & $\begin{array}{c}6.18 / 5.9 / \\
5.7 / 5.5 /\end{array}$ & $16.4 \times 5$ & $>10$ & Four \\
\hline This Work & $3.09-10.6$ & 7.2 & $30 \times 32$ & $>20$ & Single \\
\hline
\end{tabular}

\section{CONCLUSION}

Design and development of a microstrip ultra-wide band passband filter based on quadratic Koch Island fractal is presented. The quadratic Koch Island structure itself is acting as the stub loaded to the transmission line reducing the complexity of the filter structure.An ultra-wideband bandpass filter have a good rejection levels at the notch band and have a very low pass band insertion loss. Additionally, the resonant peaks of the notch band and notch bandwidth can be tuned by adjusting the notch depth t. The quality factor of the filter is inversely propostional to the bandwidth of the filter. The proposed structure finds application in removing interference signal of satellite communication which cohabits within UWB band. The filter designs are verified from the measurement and the results are in good agreement with the simulation results.

\section{REFERENCES}

[1] Ching-Luh Hsu, Fu-Chieh Hsu and Jen-Tsai Kuo. “ Microstrip Bandpass Filters for Ultra-Wideband (UWB) Wireless Communications", IEEE MTT-S International Microwave Symposium Digest, 2005.

[2] R. Gómez-García and J. I. Alonso. "Systematic Method for the Exact Synthesis of Ultra-Wideband Filtering Response Using High-Pass and Low-Pass Sections," IEEE Transactions on Microwave Theory and Techniques, Vol. 54, No. 10, 2006, pp. 3751-3764. doi:10.1109/TMTT.2006.882883.

[3] Mokhtaari, Marjan \& Bornemann, Jens \& Amari, Smain. "A Modified Design Approach for Compact UltraWideband Microstrip Filters", International Journal of $R F$ and Microwave Computer-Aided Engineering, 10.1002/mmce.20407.

[4] M. Mokhtaari, J. Bornemann, and S. Amari. "Folded Compact Ultra-Wideband Stepped-Impedance Resonator Filters,IEEE MTT-S International Microwave Symposium Digest, Honolulu, 3-8 June 2007, pp. 747-750.

[5] Wei, F, Li, W.T,Shi, X.W, Huang, Q.L. "Compact UWB bandpass filter with triple-notched bands using triple-mode stepped impedance resonator. IEEE Microw. Wirel. Compon Lett, 2012, 22, 512-514.

[6] Wei, F, Qin, P.-Y, Guo, Y.J, Shi, X.-W. "Design of multi-band bandpass filters based on stub loaded stepped impeda nce resonator with defected microstrip structure", IET Microw. Antennas Propag. 2016, 10, 230-236.

[7] Xuemei Zheng, Yuwen Pan and Tao Jiang ."UWB Bandpass Filter with Dual Notched Bands Using T-Shaped Resonator and L-Shaped Defected Microstrip Structure", Micromachines 2018, 9, 280 ; doi:10.3390/mi9060280.

[8] $\mathrm{Xu}, \mathrm{J}, \mathrm{W}$. Wu, W. Kang, and C. Miao. "Compact UWB bandpass filter with a notched band using radial stub loade resonator," IEEE Microwave and Wireless Components Letters, Vol. 22, No. 7, 351-353, July 2012.

[9] Wei, F., Z. D. Wang, F. Yang, and X. W. Shi, "Compact UWB BPF with triple-notched bands based on stub loaded resonator," IEEE Electronics Letters, Vol. 49, No. 2, 124-126, January 2013.

[10] Justin Church, David West, Pankaj Dagar and Satish K. Sharma, "A Novel Wideband Microstrip Fractal Bandpass Filter With A Notch Band at 5-6 Ghz", Microwave and Optical Technology Letters, Vol. 52, No. 6, June 2010,DOI $10.1002 / \mathrm{mop}$.

[11] Shan, Q., C. Chen, and W. Wu, "Design of an UWB bandpass filter with a notched band using asymmetric loading stubs," IEEE International Conference on Microwave and Millimeter Wave Technology (ICMMT), Vol. 2, 5-8,June 2016.

[12] Song, Y., G. M. Yang, and G. Wen, "Compact UWB bandpass filter with dual notched bands using defected ground structures," IEEE Microwave and Wireless Components Letters, Vol. 24, No. 4, 230-232, April 2014.

[13] Eman G. Ouf, Ashraf S. Mohra, Esmat A. Abdallah and Hadia Elhennawy, "Ultra-Wideband Bandpass Filter with SharpTuned Notched Band Rejection Based on CRLH Transmission-Line Unit Cell",Progress In ElectromagneticsResearch Letters, Vol. 69, 9-14, 2017.

[14] Nilotpal and Dileep Kumar Upadhyay, "A Compact UWB Bandpass Filter Based on CRLH via-less CPW-FED", Microwave And Optical Technology Letters, Vol. 58, No. 2, February 2016, DOI 10.1002/mop.

[15] Kaliyavarathan Thirumalaivasan, Rangaswamy Nakkeeran. "Development of Hexagonal MMR Based UWB bandPass Filter with $5 \mathrm{GHz}$ Notch Band",Journal of Electromagnetic Analysis and Applications, 2011, DOI: 10.4236/jemaa.2011.38054.

[16] Zheng,X.; Liu,W.;Zhang, X.;Jiang, T, "Design of dual band-notch UWB bandpass filter based on T shaped resonator",Proceedings of Progress in Electromagnetic Research Symposium, Shanghai, China, 2016; pp. 44824486. 
[17] Litesh A. Patil, P. J. Deore, J. B. Jadhav, "Ultra-Wideband (UWB) Bandpass Filter using Optimum Short Circuited Stub", Special Issue on International Journal of Electrical, Electronics and Computer System, for 3rd National Conference on Advancements in Communication, Computing and Electronics Technology [ACCET-2016].

[18] Inder Pal Singh, Praveen Bhatt, "Miniaturized Ring Resonator Wideband Bandpass Filter withWide Stop Band", Indonesian Journal of Electrical Engineering and Informatics (IJEEI), Vol. 7, No. 4, Dec 2019, pp. 686 696 ISSN: 2089-3272, DOI: 10.11591/ijeei.v7i4.950

[19] Yatindra Gaurav, R.K. Chauhan, "A Compact UWB BPF with a Notch Band using Rectangular Resonator sandwiched between Interdigital Structure", International Journal of Electrical and Computer Engineering (IJECE), Vol.7, No. 5, October 2017, DOI: 10.11591/ijece.v7i5.pp2420-2425.

[20] Imen Ben Trad, Hatem Rmili, Jean Marie Floch, Wassim Zouch, and Mohamed Drissi "Planar Square Multiband Frequency Reconfigurable Micro-strip Fed Antenna with Quadratic Koch-Island Fractal Slot for Wireless Devices", Microwave And Optical Technology Letters ,Vol. 57, No. 1, January 2015. DOI 10.1002/mop

[21] Jia-Sheng Hong and M. J.Lancaster,"Microstrip filters for RF/Microwave applications", John Wiley and sons,Inc, 2001.

[22] D.M. Pozar, Microwave Engineering, 3rd ed., John Wiley \& Sons, Inc., New York, NY, 1998.

\section{BIOGRAPHIES OF AUTHORS}

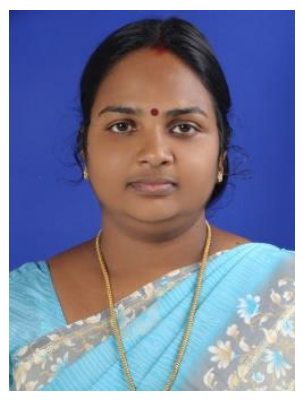

Manju Bhaskar was born on March 6th,1980 in Kochi, Kerala. She received her bachelor's degree in Electronics and Communication Engineering in 2001 from, School of Engineering, Cochin University of Science and Technolgy, Kochi, Kerala, and master's degree in Electronics and Communication with specialization in Optoelectronics and Optical communication from Department of Optoelectronics, Kerala University in 2008. She worked as faculty and Head of the Department of Electronics and Communication, KMEA Engineering College, Kochi, India from 2002 to 2018. At present she is a faculty of MGM College of Engineering and Technology, Kochi, India and is pursuing her research in Microwave Electronics at School of Technology \& Applied Sciences, Mahatma Gandhi Univerisity Regional Center, Edappally, Kochi.Her current areas of research includes RF/microwave filters for wireless and telecommunication applications.

Tel: (+91) 9995444470

Email: sudheeshmanju@gmail.com

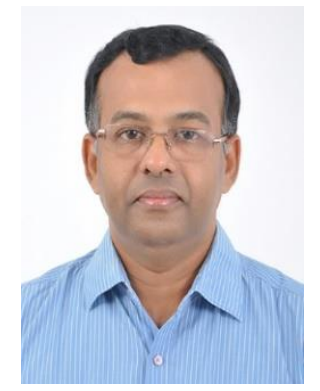

Dr.Thomaskutty Mathew received his Ph.D Degree in Microwave Electronics from Cochin University of Science and Technology Cochin, India in 1997. From 1995 to 1999 he worked as a Lecturer in Physics at Christ College, Irinjalakuda, India. From 1999 to 2019, he worked as afaculty of the Department of Electronics, School of Technology \& Applied Sciences, Mahatma Gandhi University Regional Center, Edappally, Kochi, India and presently working as Associate Professor in the Department of Physics, GITAM School of Science, GITAM University, Bengaluru Rural, Karnataka, India. During the period 2006-2008, he worked as a Post Doctoral Research Associate at Department of Electronics, University of Kent, Canterbury, U.K. His current area of research activites are in Fractal Electrodynamics, Nanoelectromagnetics, Microstrip antennas, RFID, Wireless Sensor Networks etc. He is a member of IEEE Antennas and propagation society and IET (U.K).

Tel: (+91) 9048108856

E-mail: drtkmathew@gmail.com 